\title{
PENGEMBANGAN BAHAN AJAR MATA KULIAH ALJABAR LINEAR DENGAN MENGGUNAKAN MAPLE PROGRAM STUDI PENDIDIKAN MATEMATIKA UNIVERSITAS PAHLAWAN TUANKU TAMBUSAI
}

\author{
Zulhendri $^{1}$, Adityawarman Hidayat ${ }^{2}$, Zulfah $^{3}$ \\ 1,2,3 Universitas Pahlawan Tuanku Tambusai. Jln Tuanku Tambusai No.23 Bangkinang, Riau, 28412 \\ zulhendripoenya@gmail.com
}

\begin{abstract}
The developing a learning material of aljabar linear by using maple of Mathematics education program of Pahlawan Tuanku Tambusai University. This research development was done in order to produce learning material of aljabar linear which could be used as one of the learning resources for the students of mathematic of sixth semester of Pahlawan Tuanku Tambusai University. The study was conducted based on ADDIE development model consisting of 5 steps, namely (1) analyze, (2) design, (3) development, (4) implementation and (5) evaluation. The data were collected by the use of questionnaire and interview. The collected data were analyzed descriptively based on the result of analysis of the questionnaire and interview. It was found that the developed learning material was appropriate to be applied for the students of sixth semester of mathematics education program of Pahlawan Tuanku Tambusai University.
\end{abstract}

Keywords: Learning Material of Aljabar Linear, Maple Program, Development Research

\begin{abstract}
Abstrak
Tujuan penelitian ini adalah untuk menghasilkan buku ajar mata kuliah Aljabar Linear dengan menggunakan Maple. Subyek penelitian ini adalah mahasiswa semester 6 yang berjumlah 12 orang. Metode yang digunakan adalah penelitian pengembangan ADDIE yang terdiri dari 5 tahap yaitu: (1) analisis, (2) perancangan, (3) pengembangan, (4) implementasi dan (5) implementasi. Produk penelitian ini adalah bahan ajar mata kuliah Aljabar Linear. Prototipe produk divalidasi oleh ahli desain dan ahli media, kemudian dilakukan uji perorangan dan uji kelompok. Data dikumpulkan dengan menggunakan kuesioner dan pedoman wawancara. Dari hasil kuesioner dan wawancara diketahui bahwa buku ajar yang dikembangkan layak diterapkan kepada mahasiswa. Kata Kunci: Bahan Ajar Mata Kuliah Aljabar Linear, Program Maple, Penelitian Pengembangan
\end{abstract}

Aljabar linear adalah bidang studi matematika yang mempelajari sistem persamaan linear dan solusinya, vektor, serta transformasi linear. Matrik dan operasinya juga merupakan hal yang berkaitan erat dengan mata kuliah aljabar linear. Berdasarkan hasil belajar pada mata kuliah aljabar linear pada semester sebelumnya kurang memuaskan, hal ini dikarenakan mahasiswa kurang menguasai dan kurang teliti dalam menyelesaikan soal- soal yang diberikan. Dalam penyelesaian soal-soal yang berkaitan dengan aljabar linear membutuhkan penjabaran dan uraian yang panjang sehingga membutuhkan ketelitian dan kecermatan.

Salah satu cara untuk meningkatkan komunikasi matematis belajar mahasiswa terhadap mata kuliah aljabar linear adalah dengan menggunakan teknologi. Pemanfaatan teknologi dalam pendidikan matematika sangat luas, baik sebagai media pembelajaran maupun media belajar mandiri. Pembelajaran matematika pada perguruan tinggi seperti aljabar linear, kalkulus, geometri, numerik, diskrit dan program linear pemanfaatan software-software seperti Maple, Maple, fortran, Minitab, SPSS, Lindo dan lain-lain, bedasarkan hasil-hasil penelitian menunjukkan dapat meningkatkan kemampuan berpikir tingkat tinggi serta minat belajar matematika. 
Karakteristik Matematika yang memiliki objek kajian abstrak dan membutuhkan daya pikir logis seperti materi pada aljabar linear, pemanfaatan media komputer sangat diperlukan karena pada kasuskasus yang lebih kompleks perhitungan yang dilakukan manual sangat tidak efektif dan efesien. Hal ini peneliti menawarkan sebuah program berbasis IT yang dapat digunakan pada mata kuliah aljabar linear yaitu Maple. Program ini dapat dimanfaatkan untuk meningkatkan kecepatan, dan keakuratan dalam berbagai perhitungan dalam materi aljabar linier sehingga waktu yang diperlukan untuk mengerjakan lebih efisien dan hasil yang diperoleh lebih akurat dibandingkan dengan perhitungan yang dilakukan secara manual. juga dapat memvisualisasikan grafik dalam bentuk 2 dimensi maupun 3 dimensi, yang tentu saja sulit jika digambar secara manual, sehingga diharapkan dapat meningkatkan pemahaman terhadap materi yang dipelajari.

Maple adalah program komputer yang dikembangkan pertama kali pada tahun 1980 oleh Grup Symbolic Computation di University of Waterloo Ontario, Kanada untuk keperluan bidang matematika, statistika dan komputasi aljabar. Maple adalah suatu program interaktif yang mengintegrasikan kemampuan komputasi baik numerik ataupun simbolik, visualisasi (grafik) dan pemrograman". Program Maple ini dapat dikatakan sangat canggih dan sangat membantu sekali dalam menyelesaikan soal matematika. Mulai dari membuat persamaan, grafik, mencari nilai suatu fungsi dan sebagainya.

Berdasarkan paparan permasalahan perkuliahan pendidikan matematika dan kebutuhan pembelajaran Matematika, bahan ajar yang tepat digunakan dalam memecahkan masalah bahan ajar yang dirancang menggunakan pendekatan penelitian pengembangan. Bahan ajar yang dikembangkan dikemassedemikian rupa sehingga diharapkan mampu merencanakan dan melaksanakan pembelajaran dengan pendekatan penelitian pengembngan dan dapat mendukung strategi pengembangan kompetensi berpikir kritis, kreatif dan produktif.

Temuan penelitian menunjukkan bahwa pemanfaatan bahan ajar menggunakan pendekatan research development dapat meningkatkan kualitas pembelajaran di Universitas Pahlawan Tuanku Tambusai. Dengan demikian, buku ajar aljabar linear yang menggunakan pendekatan research development diharapkan dapat meningkatkan kualitas pembelajaran di Universitas Pahlawan Tuanku Tambusai.

\section{METODE}

Dalam penelitian ini model pengembangan yang dilakukan sesuai dengan Model ADDIE. Penulis memilih Model ADDIE ini karena langkah-langkah desain sistem pembelajarannya relatif sederhana dan dapat diaplikasikan dalam jenjang pendidikan persekolahan. Hal ini sejalan menurut Benny (2009:125) bahwa salah satu model desain sistem pembelajaran yang memperlihatkan tahapantahapan dasar desain sistem pembelajaran yang sederhana dan mudah dipelajari adalah model ADDIE. Model ini sesuai dengan namanya, terdiri dari lima fase atau tahap utama, yaitu (A)nalysis, (D)esign, (D)evelopment, (I)mplementation, dan (E)valuation. 
Pengembangan Bahan Ajar Mata Kuliah Aljabar Linear dengan Menggunakan Maple Program Studi Pendidikan Matematika Universitas Pahlawan Tuanku Tambusai, Zulhendri, Adityawarman Hidayat, Zulfah

Berdasarkan model ADDIE, prosedur penelitian dan pengembangan ini dilakukan melalui lima tahap, yaitu: 1)Analisis: langkah analisis terdiri atas dua fase (Benny, 2009:125), yaitu analisis kinerja (performance analysis) dan analisis kebutuhan (need analysis). Fase pertama, analisis kinerja dilakukan untuk mengetahui apakah masalah kinerja yang dihadapi memerlukan solusi berupa penyelenggaraan program pembelajaran atau perbaikan manajemen. Dalam penelitian ini, masalah kinerja yang dihadapi yaitu penggunaan bahan ajar yang masih kurang merangsang kemampuan siswa memecahkan masalah dalam pembelajaran matematika. Masalah ini memerlukan solusi berupa pengembangan bahan ajar yang sebelumnya sudah digunakan, sehingga bisa memfasilitasi kemampuan pemecahan masalah matematis siswa. Fase kedua, analisis kebutuhan untuk menentukan kemampuan-kemampuan atau kompetensi yang perlu dipelajari oleh mahasiswa untuk meningkatkan prestasi belajar matematika khususnya kemampuan pemecahan masalah matematis, 2)Desain: pada tahap kedua ini akan didesain bahan ajar untuk memfasilitasi kemampuan mata kuliah maple pada mahasiswa dengan menetapkan judul bahan ajar. Judul bahan ajar ditentukan atas dasar kompetensi-kompetensi dasar, materi-materi pokok, atau pengalaman belajar yang terdapat dalam kurikulum dan merancang bahan ajar. Merancang bahan ajar perlu memperhatikan struktur dan penyajian materi serta format penulisannya. Selain penyusunan materi, desain cover juga perlu diperhatikan. Tampilan cover harus memiliki daya tarik tersendiri bagi mahasiswa, 3)Pengembangan: pada tahap ketiga ini, bahan ajar dikembangkan untuk memfasilitasi kemampuan pemecahan masalah matematis berdasarkan validasi ahli dan revisi produk. Bahan ajar yang dikembangkan berbentuk bahan ajar visual yang termasuk bahan ajar cetak, dirancang semenarik mungkin dan komunikatif, dilengkapi dengan gambar-gambar dan juga memperhatikan format penulisan yang sesuai. Bahan ajar yang telah dikembangkan selanjutnya divalidasi oleh ahli desain bahan ajar dan ahli materi pembelajaran matematika guna memperoleh masukan atau perbaikan, 4) implementasi: tahap keempat ini dilaksanakan setelah dinyatakan layak uji oleh ahli desain dan ahli materi, bahan ajar diujicobakan kepada mahasiswa. Uji coba pertama dilakukan pada kelompok kecil yang melibatkan 6 mahasiswa, selanjutnya uji coba kedua dilakukan pada 12 mahasiswa. Mahasiswa menggunakan dan mengevaluasi produk dengan mengisi angket respon mahasiswa. Kemudian mahasiswa diberikan tes untuk mengetahui kemampuan mahasiswa sehingga bisa mengetahui kelayakan penggunaan produk yang telah dikembangkan, dan 5) evaluasi: pada tahap akhir ini, dilakukan evaluasi terhadap kelayakan penggunaan bahan ajar yang telah dikembangkan. Evaluasi sebenarnya telah dilakukan pada empat tahap sebelumnya. Pada tahap evaluasi dilakukan penilaian terhadap bahan ajar yang dikembangkan, termasuk hasil validasi dari ahli desain dan ahli materi pada tahap pengembangan. Selain itu, juga melakukan revisi produk berdasarkan saran dan masukan saat validasi bahan ajar. Selanjutnya dilakukan evaluasi pada tahap implementasi, yaitu setelah uji coba kelompok kecil dan uji coba kelompok besar. 


\section{HASIL}

Hasil penelitian ini menghasilkan sebuah produk berupa bahan ajar. Bahan ajar sesuai dengan materi matrik dan operasi-operasinya, karena pada materi ini dibutuhkan ketelitian dan kecermatan bagi mahasiswa. Pengembangan penelitian menggunakan model pengembangan ADDIE (Analysis, Design, Development, Implementation, Evaluation), diuraikan sebagai berikut.

\section{Analysis}

Pada tahap analisis ini adalah tahap awal dalam penelitian dan pengembangan bahan ajar yang di kembangkan yang mana nantinya akan dijadikan bahan pertimbangan dalam pembuatan bahan ajar ini.

\section{Design}

Setelah tahap Analisis dilaksanakan, selanjutnya adalah tahap Desain. Tahap Desain ini peneliti merancang bahan ajar, dimana dalam perancangannya peneliti sesuaikan dengan karakteristik dan komponen-komponen yang menyusun bahan ajar tersebut.

\section{Development}

Pada tahap pengembangan terdiri dari a) Instrumen: pada tahap pengembangan, yang pertama peneliti susun berupa lembar validasi, lembar praktikalitas bahan ajar dan soal posttest. Semua instrumen yang ada itu nantinya akan peneliti gunakan sebagai alat pengambilan data penelitian, b) validasi Bahan Ajar: pada tahap pengembangan yang kedua, bahan ajar yang telah dirancang divalidasi oleh validator ahli desain yaitu bapak Kasman Ediputra, M.Si. yang merupakan dosen pendidikan matematika di Universitas Pahlawan Tuanku Tambusai. Uji validitas oleh ahli desain bertujuan untuk mengetahui kevalidan bahan ajar yang dinilai dari aspek format penulisan, bahasa yang digunakan, kemasan/tampilan bahan ajar dan penempatan gambar, sedangkan uji validitas oleh ahli materi bertujuan untuk mengetahui kevalidan bahan ajar yang dinilai dari aspek isi atau materi. Secara umum, validasi ini bertujuan untuk mengetahui sejauh mana kevalidan bahan ajar yang dirancang dan apakah bahan ajar tersebut sudah layak atau belum layak digunakan untuk diujicobakan kepada mahasiswa.

\section{Implementation}

Pada tahap implementasi terdiri dari: a) uji coba kelompok kecil: Uji coba kelompok kecil ini dilakukan guna bahan ajar yang telah dikembangkan dan dinyatakan valid dan layak digunakan oleh validator diatas dapat diujicobakan kepada kelompok kecil ( sebanyak 6 mahasiswa). Selain itu, bahan ajar yang diberikan kepada kelompok kecil juga disertai dengan mengisi lembar angket uji praktikalitas kepada mahasiswa dalam kelompok kecil tersebut, b) uji coba kelompok besar: uji coba yang dilakukan dalam skala besar yaitu peneliti laksanakan di program studi mahasiswa matematika, c) uji Kemam-puan Maple: peneliti meminta mahasiswa untuk menjawab soal-soal tentang kemampuan maple terkait pelajaran yang dipelajari dari awal hingga akhir pertemuan. Soal yang diberikan terdiri dari 5 butir soal yang berbentuk essay yang selanjutnya jawaban siswa tersebut dianalisis untuk mengetahui tingkat matematis mahasiswa. 
Pengembangan Bahan Ajar Mata Kuliah Aljabar Linear dengan Menggunakan Maple Program Studi Pendidikan Matematika Universitas Pahlawan Tuanku Tambusai, Zulhendri, Adityawarman Hidayat, Zulfah

\section{Evaluation}

Pada tahap akhir dari model ADDIE ini adalah tahap evaluasi. Tahap ini dilakukan untuk mengetahui seberapa besar kevalidan dan kepraktisan bahan ajar dengan pendekatan problem solving yang dikembangkan serta untuk kebutuhan revisi selanjutnya.

\section{Evaluasi pada Tahap Development}

1) Validasi Instrumen: Evaluasi validasi instrumen ini didapatkan bahwa hasil dari validasi menunjukkan instrumen yang telah dibuat dapat digunakan dengan revisi sedikit, yaitu pada penggunaan bahasa. Masukan dari validator digunakan untuk keperluan revisi. Selanjutnya instrumen yang telah direvisi dapat digunakan untuk kebutuhan validasi bahan ajar dan untuk soal posttest yang telah valid dapat diujikan kepada mahasiswa.

2) Validasi Ahli Desain: Evaluasi validasi ahli desain ini merupakan bahan masukan dan perbaikan bagi peneliti dalam mendesain atau merancang bahan ajar supaya nantinya bahan ajar yang dihasilkan betulbetul valid dan bisa digunakan oleh mahasiswa. Hasil penilaian tiap komponen oleh ahli desain terhadap pengembangan Bahan Ajar adalah melalui instrumen penilaian angket desain bahan ajar. Berikut peneliti sajikan hasil validasi bahan ajar oleh ahli desain.

Berdasarkan grafik hasil validasi ahli desain terhadap bahan ajar tersebut, dapat diketahui bahwa untuk aspek format penulisan diperoleh persentase nilai 55\%, aspek bahasa diperoleh persentase nilai $61 \%$, aspek tampilan diperoleh persentase nilai $82 \%$, dan aspek penempatan gambar pada bahan ajar diperoleh nilai $67 \%$. Kemudian untuk nilai validasi secara keseluruhan dari ahli desain adalah $66 \%$ yaitu kategori valid, karena berada pada rentang $61 \%$ sampai $80 \%$. Hal ini berarti bahwa bahan ajar bisa diujicobakan tanpa memerlukan revisi, namun dengan mengikuti saran perbaikan dari ahli desain. 3) Validasi Ahli Materi: Evaluasi validasi ahli materi ini merupakan bahan masukan dan perbaikan bagi peneliti dalam mendesain atau merancang bahan ajar supaya nantinya bahan ajar yang dihasilkan betulbetul memiliki materi yang sesuai dengan kebutuhan dan karakteristik siswa.

Berdasarkan grafik hasil validasi ahli materi terhadap bahan ajar aljabar linear, dapat diketahui bahwa untuk aspek isi atau materi bahan ajar aljabar linear diperoleh persentase nilai $80 \%$, aspek tujuan diperoleh persentase nilai $83 \%$. Kemudian untuk nilai validasi secara keseluruhan dari ahli materi adalah $81 \%$ yaitu kategori Sangat valid, karena berada pada rentang $81 \%$ sampai $100 \%$. Hal ini berarti bahwa bahan ajar aljabar linear bisa diujicobakan tanpa memerlukan revisi, namun dengan mengikuti saran perbaikan dari ahli materi.

\section{4)Hasil Keseluruhan Validasi Bahan Ajar (Gabungan Ahli Desain dan Ahli Materi)}

Persentase validitas keseluruhan dari penilaian ahli materi dan ahli desain terhadap pengembangan bahan ajar mata kuliah aljabar linear yaitu $73,5 \%$, ini berada pada kategori valid karena berada pada rentang $(61 \%-80 \%)$. Hal ini berarti bahwa bahan ajar aljabar linear dapat digunakan dan diujicobakan tanpa memerlukan revisi, namun dengan mengikuti saran perbaikan dari ahli desain dan ahli materi. 


\section{Evaluasi pada Tahap Implementation}

Evaluasi pada tahap implementasi ini, peneliti mengujicobakan bahan ajar aljabar linear kepada mahasiswa. Implementasi ini merupakan pelaksanaan pengerjaan dari bahan ajar yang telah dikembangkan yang nantinya diakhiri dengan hasil posttest. Data yang diperoleh dari pelaksanaannya berupa data hasil uji praktikalitas yang diambil dari mahasiswa langsung dengan menggunakan angket respon mahasiswa. Uji praktikalitas tersebut terdiri dari uji praktikalitas kelompok kecil dan uji praktikalitas kelompok besar yang mana hasilnya peneliti uraikan sebagai berikut.

\section{Hasil Praktikalitas Kelompok Kecil}

Bahan ajar yang telah dikembangkan dan dinyatakan valid oleh validator, selanjutnya peneliti mengujicobakan bahan ajar aljabar linear tersebut kepada kelompok pertama yaitu kepada 6 mahasiswa beserta angket uji praktikalitas terhadap bahan ajar yang diberikan. Dalam uji kelompok pertama diperoleh hasil persentase pada aspek pemahaman siswa terhadap materi yaitu 93\%, aspek minat siswa terhadap mahasiswa yaitu 92\%, dan penggunaan bahan ajar yaitu 95\%. Sedangkan hasil praktikalitas secara keseluruhan dari penilaian siswa yaitu 93\% dengan kategori sangat praktis.

\section{Hasil Praktikalitas Kelompok Kedua}

Hasil praktikalitas kelompok besar didapatkan setelah uji kelompok kedua. Bahan ajar telah praktis berdasarkan uji coba kelompok pertama, selanjutnya dilakukan uji coba kelompok kedua yang berjumlah 12 mahasiswa. Sama halnya dengan uji kelompok pertama, mahasiswa menggunakan dan mengerjakan bahan ajar yang peneliti berikan serta memberi penilaian melalui Dalam uji kelompok kedua diperoleh hasil persentase pada aspek pemahaman mahasiswa terhadap materi yaitu $91 \%$, aspek minat siswa terhadap bahan ajar yaitu 92\%, dan penggunaan bahan ajar yaitu 93\%. Sedangkan hasil praktikalitas secara keseluruhan dari penilaian mahasiswa yaitu 92\% dengan kategori sangat praktis.

\section{Hasil Posttest}

Hasil posttest merupakan hasil setelah mahasiswa mengikuti pembelajaran dengan menggunakan bahan ajar. Pengerjaan posttest yang diberikan kepada mahasiswa berupa soal posttest yaitu soal-soal tes tentang aljabar linear. Hasil tes kemampuan aljabar linear terhadap mahasiswa, yang berada pada interval 70-100 yaitu sebanyak 10 orang dan interval 0-69 yaitu sebanyak 2 orang. Hal ini berarti ada 10 orang dari 12 orang mahasiswa yang tuntas dalam pembelajaran aljabar linear dengan nilai di atas KKM, yaitu $\geq 70$ dengan rata-rata nilai yang diperoleh yaitu 84 (tuntas).

Produk pengembangan bahan ajar telah dinyatakan valid oleh ahli materi dan ahli desain, selanjutnya pada tahap uji coba produk diperoleh bahwa bahan ajar ini tergolong sangat praktis. Meskipun bahan ajar telah dinyatakan valid dan praktis, namun peneliti masih memperhatikan dan menyempurnakan bahan ajar sesuai saran-saran dari ahli dan siswa. Gambar pada bahan ajar terlihat monoton dan membosankan karena cuma berwarna hitam putih. Dikuatirkan bahwa banyak mahasiswa menjadi malas untuk membuka buku bahan ajar. sebaiknya cari gambar yang berwarna. setidaknya harus memiliki warna yang menarik, gambar realistic yang cocok dengan keadaan mahasiswa, serta penulisan bahan ajar harus bisa dibaca dan buat semenarik mungkin supaya materi yang ada menimbulkan minat 
Pengembangan Bahan Ajar Mata Kuliah Aljabar Linear dengan Menggunakan Maple Program Studi Pendidikan Matematika Universitas Pahlawan Tuanku Tambusai, Zulhendri, Adityawarman Hidayat, Zulfah

siswa untuk membaca dan menggunakan bahan ajar tersebut dalam pembelajaran. Peneliti disini sudah mengikuti saran-saran dari validator supaya dapat dugunakan. Berdasarkan saran dari siswa diketahui bahwa sebagian siswa belum mengerti maksud dari soal latihan yang ada dan bagaimana menyelesaikan masalah aljabar linear. Selain itu, penulisan kalimatnya terlalu singkat dan kurang jelas. Terakhir, mahasiswa menyukai gambar-gambar dengan ukuran yang cukup besar karena dengan gambar yang cukup besar, dapat menimbulkan semangat mahasiswa untuk belajar.

\section{Analisis Validasi}

\section{Validasi Ahli Desain}

Data yang telah dikumpul kemudian dianalisis dan dari hasil analisis menunjukkan bahwa bahan ajar telah dikembangkan termasuk dalam kriteria valid dengan tingkat validitas adalah $66 \%$ dan layak digunakan sebagai bahan pembelajaran. Namun sebagaimana saran yang telah diberikan yaitu tentang penggunaan gambar dan huruf dalam bahan ajar, menurut ahli desain pemilihan huruf pada cover harus jelas, karena ukuran dan jenis huruf yang digunakan sebelumnya masih kurang jelas. Selanjutnya dalam penggunaan gambar pada cover tidak sesuai, yang seharusnya divisualisasikan dengan unsur matematis yang sesuai dengan materi dalam bahan ajar tersebut serta perlu penyantuman sumber gambar. Hasil validasi yang dilakukan oleh ahli desain pada setiap aspek dapat diinterpretasikan sebagai berikut:

1) Dari segi format penulisan, bahan ajar sudah termasuk dalam kriteria cukup valid dengan persentase $66 \%$, dengan rincian: Pemilihan jenis dan ukuran huruf dengan persentase $66 \%$, ini dikarenakan jenis dan ukuran huruf pada cover yang terlalu kecil sehingga sulit untuk dibaca. Saran dari ahli desain adalah agar pengunaan huruf pada cover diganti dan ini telah direvisi sehingga sudah dapat diujicobakan.

2) Dari segi bahasa, bahan ajar sudah termasuk dalam kriteria valid dengan persentase $80 \%$, dengan rincian sebagai berikut: a)Bahasa yang digunakan mudah dipahami dengan persentase $80 \%$, yang berarti bahwa tingkat penggunaan bahasa dalam bahan ajar cukup baik, namum perlu diperbaiki supaya bisa dipahami lagi oleh mahasiswa. b)Bahasa yang digunakan komunikatif dengan persentase $80 \%$, yang berarti bahwa penggunaan bahasa dalam bahan ajar sudah komunikatif.

3) Dari segi tampilan, bahan ajar sudah termasuk dalam kriteria sangat valid dengan persentase $82 \%$, dengan rincian sebagai berikut: a) Tampilan halaman sampul bahan ajar dengan persentase $86 \%$, yang berarti bahwa desain cover/halaman sampul sudah memiliki daya tarik yang cukup baik. b) Desain tampilan dan isi bahan ajar dengan persentase $81 \%$, yang berarti bahwa desain tampilan dan isi bahan ajar sudah memiliki daya tarik yang sangat baik, c) Pemilihan warna untuk tampilan bahan ajar dengan persentase $80 \%$, yang berarti bahwa untuk tampilan bahan ajar, warna yang digunakan sudah tepat, d)

Ketepatan layout pengetikan pada penyusunan bahan ajar dengan persentase $80 \%$, yang berarti bahwa layout pengetikan sudah tepat, dan e)Kemenarikan produk bahan ajar secara keseluruhan dengan persentase $81 \%$, yang berarti bahwa dari segi desain produk bahan ajar ini sudah memiliki daya tarik yang baik.

4) Dari segi penempatan gambar, bahan ajar sudah termasuk dalam kriteria valid dengan persentase $80 \%$, dengan rincian sebagai berikut: a) Penggunaan gambar sesuai dengan ilustrasi soal dengan 
persentase $75 \%$, yang berarti bahwa penggunaan gambar sudah cukup sesuai dengan ilustrasi soal dalam bahan ajar, namun perlu disempurnakan lagi terutama permasalahan yang cukup tinggi, perlu adanya penggunaan gambar yang jelas, b) penempatan gambar jelas dan sesuai dengan persentase $95 \%$, yang berarti bahwa gambar-gambar dalam bahan ajar sudah ditempatkan pada tempat yang sesuai.

\section{Validasi Ahli Materi}

Data yang telah dikumpul kemudian dianalisis dan dari hasil analisis menunjukkan bahwa bahan ajar yang telah dikembangkan termasuk dalam kriteria sangat valid dengan tingkat validitas adalah 73,5\% dan layak digunakan sebagai bahan pembelajaran. Hasil validasi yang dilakukan oleh ahli materi pada setiap aspek dapat diinterpretasikan sebagai berikut:

1) Dari segi isi atau materi, bahan ajar sudah termasuk dalam kriteria sangat valid dengan persentase $80 \%$, dengan rincian sebagai berikut: a) Kesesuaian judul dengan materi pembelajaran dengan persentase $80 \%$, yang berarti bahwa pemilihan judul sudah sesuai dengan materi pembelajaran. b) materi pada bahan ajar sesuai dengan aljabar linear yang berlaku dengan persentase $80 \%$, c) Bahasa yang digunakan mudah dipahami mahasiswa dengan persentase $78 \%$, yang berarti bahwa penggunaan bahasa dalam bahan ajar dapat dipahami siswa dengan mudah, d) penggunaan bahasa dalam bahan ajar komunikatif dengan persentase $82 \%$, yang berarti bahwa bahasa yang digunakan dalam bahan ajar sudah komunikatif, e) materi dalam 79 sesuai dengan pengalaman atau tingkat belajar yang dirumuskan dalam silabus dengan persentase 79\%, yang berarti bahwa materi yang disajikan sudah sesuai dengan pengalaman atau tingkat belajar yang dirumuskan dalam silabus, f)Kesesuaian cakupan materi yang ingin disampaikan dengan tujuan pembelajaran dengan persentase $81 \%$, yang berarti bahwa materi yang disampaikan sudah sesuai dengan tujuan pembelajaran yang diharapkan.

2) Dari aspek tujuan, bahan ajar sudah termasuk dalam kriteria sangat valid dengan persentase $81 \%$, dengan rincian sebagai berikut: a)Bahan ajar yang dikembangkan dapat memfasilitasi kemampuan pemecahan masalah siswa dengan persentase $80 \%$, yang berarti bahwa kemampuan pemecahan masalah siswa dapat terfasilitasi dengan penggunaan bahan ajar ini, siswa mampu menjawab permasalahan yang diberikan, b)Tujuan pembelajaran dirumuskan sesuai dengan SK/KD/Kurikulum dengan persentase $82 \%$, yang berarti bahwa tujuan pembelajaran sudah dirumuskan dari SK/KD/Kurikulum. c) Soal latihan dalam bahan ajar dapat mengukur ketercapaian kompetensi dengan persentase $80 \%$, yang berarti bahwa soal latihan yang dibuat sudah dapat mengukur ketercapaian kompetensi siswa.

\section{Analisis Praktikalitas}

\section{Praktikalitas Kelompok Kecil}

Analisis praktikalitas kelompok kecil dilakukan untuk mengetahui tingkat kepraktisan bahan ajar yang dikembangkan sebelum diujicobakan kepada kelompok besar. Uji praktikalitas kelompok kecil dilakukan dengan memberikan angket dan bahan ajar kepada 6 orang mahasiswa semester 6 hal ini dikarenakan mahasiswa semester 6 pernah menjadi mahasiswa semester 3 Menurut mahasiswa, bahan 
Pengembangan Bahan Ajar Mata Kuliah Aljabar Linear dengan Menggunakan Maple Program Studi Pendidikan Matematika Universitas Pahlawan Tuanku Tambusai, Zulhendri, Adityawarman Hidayat, Zulfah

ajar ini sudah memiliki tampilan yang baik dan menarik, materi yang disajikan juga sudah lengkap dan mudah dipahami sehingga bisa menyelesaikan soal dengan baik. Dari hasil analisis uji praktikalitas kelompok kecil dapat dinyatakan bahwa bahan ajar yang telah diujicobakan kepada mahasiswa berkriteria sangat praktis dengan persentase kepraktisan yaitu 93,80\%. Hasil analisis praktikalitas pada setiap aspek dapat diinterpretasikan sebagai berikut:

1)Dilihat dari pemahaman mahasiswa terhadap bahan ajar termasuk dalam kriteria praktis dengan persentase 93\%, dengan rincian sebagai berikut: a)Mahasiswa bisa memecahkan masalah/soal dengan persentase $93 \%$, ini berarti penggunaan bahan ajar dalam pembelajaran telah dapat membuat mahasiswa memecahkan masalah/soal dengan baik. Siswa mampu menyelesaikan soal sesuai dengan yang diberikan. b)Bahan ajar memudahkan mahasiswa mempelajari aljabar linear karena berkaitan dengan dunia nyata dengan persentase $93 \%$, ini berarti materi yang disajikan dalam bahan ajar sudah berkaitan dengan dunia nyata sehingga sangat baik dalam memudahkan mahasiswa dalam mempelajari aljabar linear.

2)Dilihat dari minat mahasiswa terhadap bahan ajar termasuk dalam kriteria sangat praktis dengan persentase $92 \%$, dengan rincian sebagai berikut: a)Bahasa yang digunakan dapat memudahkan mahasiswa dalam memahami materi dengan persentase 93\%, ini berarti bahwa penggunaan bahasa dalam bahan ajar sudah sangat baik. b)Mahasiswa merasa senang dengan bahan ajar yang dilengkapi dengan gambar yang sesuai dengan ilustrasi soal dengan persentase $87 \%$, ini berarti bahwa penggunaan gambar dalam bahan ajar sudah sangat baik sehingga mahasiswa merasa senang dengan bahan ajar. c)Bahan ajar yang dibuat memiliki tampilan yang menarik dengan persentase $96 \%$, ini berarti bahwa tampilan bahan ajar sudah sangat baik.

3) Dilihat dari penggunaan bahan ajar termasuk dalam kriteria sangat praktis dengan persentase $95 \%$, dengan rincian sebagai berikut: a)Mahasiswa bisa menggunakan bahan ajar secara mandiri dengan persentase $96 \%$, ini berarti bahwa penggunaan bahan ajar secara mandiri oleh mahasiswa sudah sangat baik. b) Mahasiswa lebih mudah menggunakan bahan ajar karena terdapat kolom-kolom/kotak isian untuk menjawab soal dengan persentase $94 \%$, ini berarti bahwa penggunaaan kolom-kolom/kotak isian pada bahan ajar sudah sangat baik dan membantu siswa dalam menggunakan bahan ajar dalam menjawab persoalan yang diberikan.

\section{Praktikalitas Kelompok Kedua}

Analisis praktikalitas kelompok besar dilakukan untuk mengetahui tingkat kepraktisan bahan ajar yang dikembangkan setelah uji coba kelompok kecil, dengan memberikan angket dan bahan ajar kepada mahasiswa. Menurut Mahasiswa, bahan ajar ini sudah memiliki tampilan yang baik dan menarik, materi yang disajikan juga sudah lengkap dan mudah dipahami sehingga bisa menyelesaikan soal dengan baik. Dari hasil analisis uji praktikalitas dapat dinyatakan bahwa bahan ajar yang telah diujicobakan kepada mahasiswa berkriteria sangat praktis dengan persentase kepraktisan yaitu 91\%. Hasil analisis praktikalitas pada setiap aspek dapat diinterpretasikan sebagai berikut: 
1) Dilihat dari pemahaman mahasiswa terhadap materi bahan ajar termasuk dalam kriteria sangat praktis dengan persentase $90 \%$, dengan rincian sebagai berikut: a)Mahasiswa bisa memecahkan masalah/soal dengan persentase $89 \%$, ini berarti penggunaan bahan ajar dalam pembelajaran telah dapat membuat siswa memecahkan masalah/soal dengan sangat baik, mahasiswa merasa terbantu dalam memecahkan masalah/soal yang diberikan. b) Bahan ajar ini memudahkan mahasiswa mempelajari aljabar linear karena berkaitan dengan dunia nyata dengan persentase $91 \%$, ini berarti materi yang disajikan dalam bahan ajar sangat baik dalam memudahkan mahasiswa dalam mempelajari aljabar linear.

2) Dilihat dari minat mahasiswa terhadap bahan ajar termasuk dalam kriteria sangat praktis dengan persentase $91 \%$, dengan rincian sebagai berikut: a)Bahasa yang digunakan dapat memudahkan siswa dalam memahami materi dengan persentase $88 \%$, ini berarti bahwa penggunaan bahasa dalam bahan ajar sudah sangat baik. b) Mahasiswa merasa senang dengan bahan ajar yang dilengkapi dengan gambar yang sesuai dengan ilustrasi soal dengan persentase $92 \%$, ini berarti bahwa penggunaan gambar dalam bahan ajar sudah sangat baik sehingga mahasiswa merasa senang dengan bahan ajar dan membuat siswa tertarik untuk membaca dan menggunakan bahan ajar.

3) Dilihat dari penggunaan bahan ajar termasuk dalam kriteria sangat praktis dengan persentase $92 \%$, Hal ini membuktikan bahwa mahasiswa bisa menggunakan bahan ajar secara mandiri

\section{Analisis Kemampuan Mahasiswa Dalam Aljabar Linear}

Setelah mahasiswa mengikuti pembelajaran dengan menggunakan bahan ajar aljabar linear, mahasiswa diberi soal posttest berupa tes pemecahan masalah aljabar linear. Hasil posttest tersebut menyatakan bahwa terdapat 9 mahasiswa telah tuntas dalam pembelajaran dan 3 mahasiswa tidak tuntas karena nilai yang diperoleh berada di bawah KKM. Namun secara keseluruhan, tingkat kemampuan pemecahan masalah siswa tergolong baik dengan persentase nilai $84 \%$. Berikut akan dijelaskan tingkat kemampuan mahasiswa dalam menyelesaikan soal aljabar linear. a)Indikator pertama yaitu kemampuan dalam memahami masalah dengan tingkat persentase $86 \%$. Dengan demikian secara umum mahasiswa telah mampu memahami masalah dengan sangat baik. b).Indikator kedua yaitu dalam merencanakan penyelesaian sudah mencapai tingkat persentase $82 \%$. Dengan demikian secara umum mahasiswa telah mampu membuat rencana penyelesaian masalah dengan sangat baik. c). Indikator ketiga yaitu kemampuan dalam melaksanakan penyelesaian dengan tingkat persentase $83 \%$. Dengan demikian secara umum mahasiswa telah mampu melaksanakan penyelesaian sesuai dengan perencanaan penyelesaian dengan baik. d).Indikator keempat yaitu memeriksa kembali dengan tingkat persentase 88\%. Ini dikarenakan ada sebagian mahasiswa tidak melakukan pengecekan kembali, namun mahasiswa telah mampu memeriksa kembali jawaban yang telah diperolehnya dengan baik.

Berdasarkan rincian hasil analisis tingkat kemampuan menyelesaikan soal aljabar linear pada tiap indikator tersebut, tingkat kemampuan mengerjakan soal yang berkaitan dengan aljabar linear secara keseluruhan sudah baik dengan tingkat persentase mencapai $84 \%$. Jadi, dapat dikatakan bahwa bahan ajar ini dapat memfasilitasi kemampuan mahasiswa terhadap aljabar linear. 
Pengembangan Bahan Ajar Mata Kuliah Aljabar Linear dengan Menggunakan Maple Program Studi Pendidikan Matematika Universitas Pahlawan Tuanku Tambusai, Zulhendri, Adityawarman Hidayat, Zulfah

\section{KESIMPULAN}

Berdasarkan hasil penelitian dan pembahasan yang telah diuraikan, maka dapat diberikan kesimpulan terhadap penelitian ini yaitu sebagai berikut: 1). Bahan ajar aljabar linear dapat dikembangkan sesuai dengan standar kompetensi dan kompetensi dasar yang mana materi-materi yang ada dapat membimbing mahasiswa untuk belajar dengan pemecahan masalah sehingga mahasiswa memiliki minat untuk belajar.2). Bahan ajar aljabar linear yang dikembangkan sangat layak dijadikan sebagai bahan pembelajaran. 3). Bahan ajar aljabar linear memberikan dampak yang positif serta efektif terhadap kemampuan belajar matematika khususnya kemampuan pemecahan masalah matematis mahasiswa.

\section{DAFTAR PUSTAKA}

Anton, Howard. (2000). Dasar-Dasar Aljabar Linear Edisi 7 Jilid 1. Interaksara. Batam.

Chairani, Yuni. (2011). Pembelajaran Matematika Dengan Software Geogebra Untuk Meningkatkan Kemampuan Pemahaman Konsep Siswa Dengan Model Pembelajaran Ekslorasi. Makalah UPI Bandung: Tidak diterbitkan

Dewimarni, Syelfia. 2017. "Kemampuan Komunikasi Dan Pemahaman Konsep Aljabar Linier Mahasiswa Universitas Putra INdonesia „YPTK ${ }^{e}$ Padang.” Al-Jabar: Jurnal Pendidikan Matematika8 (1): 53-62.

Leon, J. Steven. 2001. Aljabar Linear Dan Aplikasinya. 5rded. Jakarta: Erlangga:1.

Margono. 2000. Metodologi Penelitian Pendidikan. Jakarta: Rineka Cipta

Purnomo, Djoko. (2011). Pengembangan Bahan Ajar Matematika Sebagai Sarana Pengembangan Kreativitas Berpikir. Makalah Jurusan Pendidikan Matematika FPMIPA IKIP PGRI Semarang Sudijono, Anas. 2006. Pengantar Evaluasi Pendidikan. Jakarta: Raja Grafindo

Sugiyono. 2015. Metode Penelitian \& Pengembangan (Research and Development). Bandung: Alfabeta.

Sujana, Nana. 2008. Penilian Hasil Proses Belajar Mengajar. Bandung:Remaja Rosda karya Sukmadinata, Nana Syaodih. 2005. Metode Penelitian Pendidikan. Bandung: Remaja Rosdakarya. 